\title{
The analysis of foreign economic activity of agricultural producers of the southern federal district
}

\author{
Andrey Udalov ${ }^{1, *}$, and Zoya Udalova ${ }^{2}$ \\ ${ }^{1}$ Don State Technical University, sq. Gagarina, 1, Rostov-on-Don, 344000, Russia \\ ${ }^{2}$ Rostov State Economic University, Bolshaya Sadovaya str., 69, Rostov-on-Don, 344002, Russia
}

\begin{abstract}
The article presents an analysis of the foreign economic activity of agricultural producers in the Southern Federal District. The general results of foreign trade of the constituent entities of the Russian Federation located in the Southern Federal District are considered. The general characteristic of the foreign trade activity of the Southern Federal District is provided, providing for an assessment of the value volumes and per capita indicators of export and import, foreign trade turnover, and the balance of foreign trade balance.
\end{abstract}

During the coronavirus pandemic declared by the World Health Organization (WHO), every production, including agricultural producers, seeks to survive, trying to minimize losses. Despite the fact that the state is developing anti-crisis plans and measures to support any type of business, each company should analyze all areas of its activities for potential risks.

The production and sale of agricultural products is most associated with the likelihood of situations leading to loss of profit, financial instability and bankruptcy. This can be explained by the fact that the volume of agricultural output is influenced not only by the volume of investments, labor costs, but also by the objective climatic conditions and biological laws, so investing in this sector of the economy is quite risky [1].

Foreign economic activity (FEA) is subjected to additional risks, the main of which can be for importers failure to meet delivery terms for the exporters in turn, there is the risk of non-receipt of export proceeds. One way of solving these problems and minimizing new risks, it is necessary to consider the complexity of the situation present, and to analyze the dynamics of previous years foreign trade activities on the example of the SFD.

Southern Federal District plays the key role in ensuring food security of the Russian Federation is focused here almost 6-th part of the total acreage of the country, which is grown more than a quarter of Russian gross harvest of grain crops, half of the total harvest of sunflower seeds, a fifth of the harvest of vegetables. Three of the subject district is comprised of the top twenty subjects of the Russian Federation on manufacture of agricultural production: Krasnodar Territory, Rostov and Volgograd regions. These entities produce $90 \%$ of the district 's agricultural output.

\footnotetext{
* Corresponding author: Udalov717@yandex.ru
} 
Southern Federal district is considered the granary of the country, annually providing more than $25 \%$ of the Russian gross harvest of grain and leguminous crops. Currently, the district occupies third place in Russia on volumes of production of agricultural products.

The main task of the Russian Federation is the increase revenues from agricultural exports. And this task has become one of the most important in the development of the economy of the South Russian regions. This is due to the fact that the Southern Federal district produces a large share of agricultural products, in addition, the Kuban and Rostov region have exits to Black Sea and Azov Sea. The shipment of products for export is growing annually. Thus, in 2019, the Group NCSP (Novorossiysk commercial seaport) has recorded the turnover of private agricultural production of about 3 million tons., however, compared to the same period in 2018, it decreased by $44.4 \%$ [2].

Analyzing the foreign trade potential of the Southern Federal District, it should be noted that the region under consideration provides about $4 \%$ of Russia's foreign trade flows, and the Rostov Region and Krasnodar Territory are among the 15 largest regions of Russia in terms of turnover. However, in some articles, the positions of the Southern Federal District are very significant and even decisive [3].

According to forecasts of the Ministry of Agriculture, by 2024 the Southern Federal District will increase agricultural exports by almost one and a half times: from the current 8.4 billion to 12.2 billion dollars. The share of the Southern Federal District in the total volume of planned Russian exports will be $27.1 \%$, which will allow the district to take a leading position on exports in the country. In order to achieve export targets, the Southern Federal District should not only develop transport and logistics infrastructure, but also significantly increase agricultural production by 2024. In particular, it is necessary to increase the gross harvest of grain crops - up to 35.6 million tons, oilseeds - up to 6.7 million tons. Cattle and poultry production should also be increased to 1.7 million tons, and milk production to 4 million tons.

In addition, the Southern Federal District is the absolute leader in sending grain for export through seaports - in 2018, the volume of transshipment amounted to 45.7 million tons, or $95 \%$ of the total Russian indicator [4].

Thus, the south of Russia provides more than half of the country's exports for cereals, oilseeds, vegetables, a third - for fats and oils, a quarter - for tobacco. As for imports, this is a quarter of Russian volumes of vegetables, fruits, grains, a sixth of metals. The district provides almost 30\% of Russia's foreign trade with Egypt, a quarter - with Israel and Iran, Cyprus, a sixth - with Turkey.

Since the economy of the Southern Federal District is open, integrated into the global economic space, the degree of integration of the region into the system of international economic relations is determined by the ratio of export, import and foreign trade quotas. A general assessment of the competitiveness of the region and its main industries can be established using the equilibrium coefficient of foreign trade relations [5].

Consider the equilibrium coefficient of foreign trade relations for the Southern Federal District.The equilibrium coefficient of foreign trade relations $\left(I_{0}\right)$ is calculated by the formula:

$$
I_{0}=(E-M) / F F T,
$$

where:

E - region export volume;

$\mathrm{M}$ - region import volume;

FFT - foreign trade turnover of the region.

Let's calculate this ratio:

$I_{2018}=(20408,69-9$ 463,44 $) / 29$ 872,13 = 0,37;

$I_{2018}=(17055,12-7923,76) / 24978,88=0,37$. 
The emphasis on the development of international trade and cooperation made it possible to increase the investment climate in the Russian Federation. Russia has gained access to international technologies on an equal footing with other states, which in the future is a factor contributing to intensive economic growth. A relative balance was struck between the accelerated integration of the country into the world economy and the protection of its own production [6].

General results of foreign trade of the constituent entities of the Russian Federation located on the territory of the Southern Federal District for 2018-2019 are given in table 1.

Table 1. General results of foreign trade of the constituent entities of the Russian Federation located on the territory of the Southern Federal District for 2018-2019*

\begin{tabular}{|c|c|c|c|c|c|c|c|c|c|}
\hline \multirow[b]{2}{*}{$\begin{array}{c}\text { Name of } \\
\text { subject }\end{array}$} & \multicolumn{3}{|c|}{ 2018, million US dollars } & \multicolumn{3}{|c|}{ 2019, million US dollars } & \multicolumn{3}{|c|}{ Growth rate $2019 / 2018, \%$} \\
\hline & import & export & $\begin{array}{c}\text { trade } \\
\text { turnove } \\
\mathrm{r}\end{array}$ & import & export & $\begin{array}{l}\text { trade } \\
\text { turnove }\end{array}$ & import & export & $\begin{array}{c}\text { trade } \\
\text { turnov } \\
\mathrm{e}\end{array}$ \\
\hline $\begin{array}{l}\text { Krasnodar } \\
\text { Territory }\end{array}$ & 4752,51 & 8430,01 & 13182,52 & 4191,99 & 7175,86 & 11367,85 & 88,21 & 85,12 & 86,23 \\
\hline Rostov region & 3050,94 & 9053,81 & 12104,76 & 2790,00 & 7938,98 & 10728,98 & 91,45 & 87,69 & 88,63 \\
\hline $\begin{array}{l}\text { Volgograd } \\
\text { region }\end{array}$ & 906,95 & 1913,75 & 2820,70 & 696,04 & 1378,45 & 2074,49 & 76,75 & 72,03 & 73,55 \\
\hline $\begin{array}{l}\text { Astrakhan } \\
\text { region }\end{array}$ & 647,98 & 951,10 & 1599,08 & 129,15 & 504,65 & 633,81 & 19,93 & 53,06 & 39,64 \\
\hline $\begin{array}{l}\text { Republic of } \\
\text { Adygea }\end{array}$ & 55,79 & 40,30 & 96,09 & 68,16 & 28,43 & 96,59 & 122,18 & 70,54 & 100,52 \\
\hline $\begin{array}{l}\begin{array}{l}\text { Republic of } \\
\text { Crimea }\end{array} \\
\end{array}$ & 40,67 & 17,75 & 58,42 & 44,43 & 25,32 & 69,74 & 109,26 & 142,59 & 119,39 \\
\hline $\begin{array}{l}\text { Sevastopol is a } \\
\text { city of federal } \\
\text { significance }\end{array}$ & 4,02 & 1,95 & 5,96 & 3,79 & 3,25 & 7,03 & 94,26 & 166,84 & 117,95 \\
\hline $\begin{array}{l}\text { Republic of } \\
\text { Kalmykia }\end{array}$ & 4,59 & 0,01 & 4,60 & 0,19 & 0,19 & 0,38 & 4,15 & 1273,45 & 8,19 \\
\hline Total & 9463,44 & 20408,69 & 29 872,13 & 7923,76 & 17 055,12 & 24 978,88 & 83,73 & 83,57 & 83,62 \\
\hline
\end{tabular}

* - preliminary data

Source: compiled from materials [7]

According to data published by Rosstat, the total foreign trade turnover of the Southern Federal District amounted to 29,872.13 million US dollars in 2018, and 24,978.88 million US dollars in 2019. The growth rate for the analyzed period was $83.62 \%$. The main volumes of export deliveries were provided by: Krasnodar Territory - half of the value, Rostov Region - a quarter, Volgograd Region - a fifth. Regional leaders in terms of trade turnover in 2018 and 2019 are: the Krasnodar Territory (13,182.52 million US dollars and 11,367.85 million US dollars, respectively) and the Rostov region (12,104.76 million US dollars and 10,728.98 million US dollars, respectively). The growth rate for the period 2018-2019 in the Krasnodar Territory for imports amounted to $88.21 \%$, for exports 85.12\% (for trade turnover - 86.23\%); in the Rostov Region, import - 91.45\%, export $87.69 \%$ (for trade turnover - $88.63 \%$ ).

In 2019, the value of exports to the Southern Federal District is estimated at 17.1 billion US dollars, or $84 \%$ of the level of 2018 (20.4 billion US dollars). The main volumes of export deliveries of the Southern Federal District in 2019 were provided by: Rostov Region (46.6\% of the value), Krasnodar Territory (42.1\%) and Volgograd Region (8.1\%).

In 2019, the commodity structure of exports of the Southern Federal District determined the leading positions in food products and agricultural raw materials for their production, which accounted for $42.8 \%$ of the value (in $2018-41.2 \%$ ), mineral products $-35.4 \%$ (in 2018 - 36.1\%), metals and products from them - 9.8\% (in $2018-9.5 \%$ ). The value of 
exports of food products and agricultural raw materials for their production amounted to about 7.3 billion US dollars or $87 \%$ of the level of 2018 (8.4 billion US dollars). The main exports were cereals ( 4.7 billion US dollars), fats and oils (1.2 billion US dollars), residues and waste from the food industry (362.1 million US dollars), vegetables (259.0 million US dollars), as well as oilseeds (237.3 million US dollars). The leading exporters of agricultural products were participants in foreign economic activity of the Rostov Region (60.5\% of the value or 4.4 billion US dollars) and the Krasnodar Territory (33.9\% or 2.5 billion US dollars).

The value volumes of imports of the Southern Federal District amounted to about 7.9 billion US dollars or 83\% compared to the level of 2018 (9.5 billion US dollars). The main value volumes of imports in 2019 were provided by the Krasnodar Territory (53\% of the value), Rostov (35.2\%) and Volgograd (8.8\%) regions.

The commodity structure of 2019 imports mainly include food products and agricultural raw materials for their production, which accounted for $32.7 \%$ of the import value (in 2018 - 30.4\%), machine-building products - 25.6\% (in 2018 - 32,2\%), metals and products from them - 13.6\% (in 2018 - 12.3\%), chemical products - 11.2\% (in 2018 - 9.7\%).

The value of imports of food products and agricultural raw materials for their production amounted to 2.6 billion US dollars, or $89.7 \%$ of the 2018 volumes (2.9 billion US dollars). Food imports are based on fruits (1.0 billion US dollars), animal and vegetable fats and oils ( 0.4 billion US dollars), vegetables ( 0.3 billion US dollars), oilseeds ( 0.2 billion US dollars). The leading importers of food products were participants of foreign economic activity of the Krasnodar Territory, which accounted for $84.5 \%$ of the value or 2.2 billion US dollars.

If we delve into the analysis of the results of foreign trade of the constituent entities of the Russian Federation, it should be noted that since 2015, there has been a noticeable reduction in the volume of foreign trade turnover compared to 2014, moreover, both in terms of export and import, which, of course, was caused by EU sanctions and the depreciation of the ruble against other currencies.

It can be stated that «...economic sanctions and import substitution policies for the development of the productive potential of Russian agriculture play an important role, both in the production and processing of raw materials, due to the duration of business processes, high level of dependence on environmental conditions, difficulties related to the storage and transportation of agricultural products. In this regard, a market-type economy dictates the need to use fundamentally new conceptual approaches in the development of the agricultural business of our country»[8].

However, with further plans to increase the export of the industry, two problems should be highlighted.Firstly, in the export development project, the government is betting on increasing sales of finished products with high added value. Today, the Southern Federal District is increasing grain sales. At the same time, technologies are developing, new efficient varieties appear, and productivity increases. According to the project "Export of agricultural products”, grain revenues should increase from 7.6 billion US dollars in 2019 to 11.4 in 2024 [9]. In order to implement this project, it is necessary to triple the export of meat and dairy products and double the export of oil and fat. This will require serious modernization of capacities, the purchase of modern technologies, the expansion of the raw material base and so on. Estimates of the necessary investments vary, but in any case, it will understand hundreds of billions of rubles of credit funds. Secondly, there is an excessive dependence on state financing. The state allocates money for development, but such projects need more private capital. In addition, today far from all financial institutions want to engage in agro-industrial complex. 
Currently, the Ministry of Agriculture of Russia is increasing support for agricultural exports. Of the 957 billion rubles allocated for the national project "International Cooperation and Export”, more than 400 billion rubles were allocated to this sphere.

The head of the Ministry, Dmitry Patrushev, speaking at the July meeting on stimulating the export of agricultural products, said that in addition to the already existing mechanism for issuing soft loans, a new type of support appeared - lending to agribusiness companies focused on the international market [10].

In the Russian regions, they are afraid of a bias towards state financing. For example, in the passport of the regional project "Export of agricultural products" of the Rostov Region, one of the main risks that may impede its implementation (in addition to a few obvious ones, such as natural disasters and epidemics), is "a reduction of state financing of export enterprises due to the emergence of other priorities, which may lead to the impossibility of implementing most of the financial and non-financial support measures provided for by the project." In other words, it is better to "diversify” project financing as much as possible.

Thus, the Southern Federal District is quite actively involved in foreign economic activity, and during the analyzed period the export of the macro-region dominated imports. The level of participation in foreign economic activity of individual regions of the Southern Federal District is uneven. So, for example, the regions that make the largest contribution to the foreign economic activity of the Southern Federal District were distinguished: Krasnodar Territory and Rostov Region, which determined the dominant group of regions. Such outsider regions as the Republics of Adygea and Kalmykia were included in the small group.

\section{References}

1. Zoya Udalova, Ksenia Burtseva, Aleksandr Alekseev, Andrey Udalov IOP Conf. Ser.: Earth Environ. Sci. 403. 012130 (2019)]

2. Official data of the NCSP website. URL: - http://nmtp.info/holding/presscentre/news/news_detail.php?ID=9403

3. Basenko A.M., Ishanov I.V. Peculiarities of foreign trade turnover of the Southern Federal District /A.M. Basenko, I.V. Ishanov//Financial research. № 3 (60). (2018). P. 31-34

4. The export of agricultural products from the Southern Federal District will increase almost one and a half times by 2024. URL: - http://mcx.ru/press-service/news/eksportproduktsii-apk-iz-yufo-uvelichitsya-pochti-v-poltora-raza-k-2024-godu/

5. Kryuchkova M.A., Romantseva V.E., Maldova E.S. The analysis of the main indicators of foreign trade of the Southern Federal District / M.A. Kryuchkova, V.E. Romantseva, E.S. Maldova // Science time. Publishing House: Individual Entrepreneur Kuzmin Sergey Vladimirovich (Kazan). No. 12. (2015).P. 435-443

6. Andrey Udalov, Zoya Udalova, Lyubov Postnikova ICEMT 2020 Ser.: Advances in Economics, Business and Management Research. Vol. 139. (2020) DOI: https://doi.org/10.2991/aebmr.k.200509.069

7. Regions of Russia. Socio-economic indicators. 2019: P32 Stat. Sat / Rosstat. M., 2019. 1204 p.

8. Andrey Udalov, Zoya Udalova, Darya Postnikova, Lyubov Postnikova IOP Conf. Ser.: Earth Environ. Sci. 403. 012148 (2019)

9. The passport of the national project (program) "International Cooperation and Export"(approved by the Presidium of the Presidential Council for Strategic Development and National Projects, protocol No. 16, dated 12.24.2018). Access Mode ATP Consultant-Plus 
10. By 2024, farmers in the Southern Federal District intend to double their income from the sale of agricultural products on the world market. URL: https://rg.ru/2019/10/15/reg-ufo/k-2024-godu-agrarii-iufo-namereny-udvoit-dohody-namirovom-rynke.html 